Journal of International Business and Economy (2020) (2): 1-31 (31 pages)

JIBE

Nathalia Roller

\title{
A GENERALIZED DOUBLE DIAMOND APPROACH TO THE GLOBAL COMPETITIVENESS OF THE PHARMACEUTICAL INDUSTRY: \\ A COMPARISON BETWEEN SOUTH KOREA AND JAPAN
}

\begin{abstract}
A competitive pharmaceutical industry is integral for the continued improvement of any country's social and health resources and can be a source of sustained economic growth. As South Korea faces economic slowdown and increased social and health costs from an aged population, it is necessary to examine the current state of the industry's competitiveness to determine how its global position can be enhanced. The following study identifies the determinants of South Korea's competitiveness by applying the Generalized Double Diamond Model and conducts a comparative analysis with the globally competitive country of Japan. As the pharmaceutical industry is highly globalized, the study explores both domestic and international variables at the country and industry level ranging from 2015 to 2019. The results indicate that although South Korea almost matches Japan's level of domestically determined competitiveness, there are significant international strategic differences that are hindering South Korea from becoming as globally competitive as Japan.

Key Words: Pharmaceutical Industry, Generalized Double Diamond Model, South Korea, Japan, International Competitiveness
\end{abstract}

Nathalia Roller

Graduate School of International Studies, Seoul National University

Correspondence: Nathalia Roller

E-mail:nathaliaroller@gmail.com

Journal of International Business and Economy

Fall 2020 


\section{INTRODUCTION}

With the rise of innovation-based high technology industries, such as semiconductors, automobiles, and telecommunications, South Korea has transformed itself into one of the largest economies globally (Kim and Lee, 2019). However, given the growing price competitiveness of new entrants in the aforementioned industries, the South Korean government seeks to address limitations to its export-led growth strategy and identify higher value-add activities and sectors that will draw in capital investment from abroad and be the future growth engine for its economy. One such industry is the pharmaceutical industry (KHIDI, 2018).

Pharmaceutical exports have grown faster than all other manufactured goods, growing at a rate of 4.3 percent between 2008 and 2018 (WTO, 2019). To support this growth, the industry is undergoing large structural changes that are providing new players an immense opportunity to capture international market share (Gambardella, Orsenigo, and Pammolli, 2000). South Korea in particular is forecasted to grow between 3 to 6 percent in 2021 and is picked to be a key source of future domestic employment. Whilst the economic benefit of a growing pharmaceutical industry is apparent, it's impact on social and health indicators must not be overlooked. South Korea faces increased pressure on its Universal Health System, and critics are wary of the difficulties that will arise from the country's rapidly aging population if the country is unable to ensure the development and effective allocation of health and social resources. Policy-makers must therefore have a full understanding of the industry and which determinants will ensure its sustained growth and continued international competitiveness.

Though the industry has been extensively studied, there is a gap in the existing literature into the rapidly growing South Korean pharmaceutical industry by comparing its competitiveness with the mature Japanese industry. In addition, researchers have argued for the suitability of comparative research into Japanese and South Korean manufacturing industries, given the comparable level of economic developments, factor endowments, geographical proximity, and more (Fukao, Kim, Kwon, and Makino, 2016). Both countries factor in each other's top three pharmaceutical export destinations worldwide from 20172019 and are therefore greatly influencing demand conditions and sales volumes in each other's pharmaceutical industry. As a regional leader in the industry, an analysis of Japan's pharmaceutical market conditions and the policies implemented by the government can therefore help determine which strategies South Korean pharmaceutical firms should 
implement to succeed in the future and surpass their historically more mature Japanese counterparts.

This study will contribute to the existing literature by quantifying and comparing the international competitiveness of the Korean and Japanese pharmaceutical industries through the application of the Generalized Double Diamond Model (referred to throughout the rest of the study as the GDDM). The study finds that the domestic competitiveness of the Korean pharmaceutical industry is comparable to Japan's, with little difference across all determinants. The main difference between the industries arises from international competitiveness. If South Korea is to succeed in catching up with Japan as an international leader in the pharmaceutical industry, it should ensure that policies incentivize FDI inflow and outflow.

\section{LITERATURE REVIEW}

There is an abundance of literature that addresses the fundamental drivers of competitive advantage in the pharmaceutical industry. By changing the macro-environment through regulations that incentivize innovation and promote international trade, studies show that the government exerts a large influence on the competitiveness of pharmaceutical corporations and their ability to explore internationalization strategies (Pease, 2005; Galović, 2015; Agrawal, 1999; Keyhani et al.,2010; Gambardella, et al., 2020). Furthermore, outsourcing elements of the pharmaceutical supply chain, adopting disruptive business models, and actively engaging in mergers and acquisitions are boosting the ability of firms to compete for both domestically and internationally, given the larger propensity they then have to work on innovative projects (Ku, 2015; Mishra and Jaiswal, 2017). In terms of developing clinical capabilities and the overall pharmaceutical success of a country, authors found it to be vital to address R\&D financing resources, R\&D intensity, and patent quality (Kuwashima, 1999; Lakner et al., 2019; Gambardella, et al., 2020; Chung et al.,2019; Chen and Chang, 2010), and Human Capital (Shabaninejad, Mehralian, Rashdian, Baratimarnani, and Rasekh, 2014). Lastly, some experts argued for the economic and operational benefit that firms gain when bringing products to new markets, conducting investments abroad, and internationalizing their patents (Laurens et al., 2019; Pradhan, 2006; Bergman, 2006).

These aforementioned authors have all established specific factors that contribute to the competitiveness of the pharmaceutical industry, but do not simultaneously and sufficiently evaluate all factors that may influence the level of competitiveness of a country. 
As shown in previous literature, the performance of the pharmaceutical industry is impacted not only by the characteristics and strategies of individual firms, but also by factors at the national level. Therefore, this study will utilize the GDDM to provide a comprehensive view of the pharmaceutical industry, and to identify specific areas that would contribute to the improvements of South Korea's performance.

The table below shows a comparison of the determinants analyzed by some of the utilized previous studies and the generalized double diamond model and demonstrates that they have insufficiently addressed all the necessary dimensions.

Table 1: A comparison of previous studies and the Generalized Double Diamond Model

\begin{tabular}{|c|c|c|c|c|c|}
\hline Studies & $\begin{array}{c}\text { Factor } \\
\text { Conditions }\end{array}$ & $\begin{array}{c}\text { Demand } \\
\text { Conditions }\end{array}$ & $\begin{array}{l}\text { Related and } \\
\text { Supporting } \\
\text { Industries }\end{array}$ & $\begin{array}{l}\text { Firm Strategy, } \\
\text { Structure and } \\
\text { Rivalry }\end{array}$ & $\begin{array}{l}\text { Government } \\
\text { and Chance }\end{array}$ \\
\hline $\begin{array}{l}\text { Gambardella } \\
\text { et al., } 2020\end{array}$ & $\mathrm{O}$ & $\mathrm{O}$ & $\mathrm{O}$ & $\mathrm{O}$ & \\
\hline Ku, 2015 & & & & $\mathrm{O}$ & \\
\hline Kuwashima,1999 & & & & $\mathrm{O}$ & \\
\hline $\begin{array}{c}\text { Olmeda and } \\
\text { Sosa-Varela, } \\
2012\end{array}$ & $\mathrm{O}$ & $\mathrm{O}$ & $\mathrm{O}$ & $\mathrm{O}$ & $\mathrm{O}$ \\
\hline $\begin{array}{c}\text { Mishra, and } \\
\text { Jaiswal, } 2017\end{array}$ & & & & $\mathrm{O}$ & \\
\hline $\begin{array}{l}\text { Lakner et al., } \\
2019\end{array}$ & $\mathrm{O}$ & & & $\mathrm{O}$ & $\mathrm{O}$ \\
\hline $\begin{array}{l}\text { Shabaninejad et } \\
\text { al., } 2014\end{array}$ & $\mathrm{O}$ & & $\mathrm{O}$ & $\mathrm{O}$ & \\
\hline Agrawal, 1999 & $\mathrm{O}$ & & & $\mathrm{O}$ & $\mathrm{O}$ \\
\hline Galović, 2015 & & & $\mathrm{O}$ & & $\mathrm{O}$ \\
\hline Keyhani, 2010 & $\mathrm{O}$ & & & & $\mathrm{O}$ \\
\hline $\begin{array}{l}\text { Chen and } \\
\text { Chang, } 2010\end{array}$ & & & $\mathrm{O}$ & & \\
\hline Bergman, 2006 & $\mathrm{O}$ & & & $\mathrm{O}$ & \\
\hline Pradhan, 2006 & & & & $\mathrm{O}$ & $\mathrm{O}$ \\
\hline $\begin{array}{l}\text { Laurens et al., } \\
2019\end{array}$ & & & $\mathrm{O}$ & $\mathrm{O}$ & \\
\hline
\end{tabular}




\section{THEORETICAL MODEL}

Given the extent to which the industry is highly internationalized (Shabaninejad et al., 2014;), this thesis aims to analyze the industrial competitiveness of Korea and Japan through the GDDM (Moon, Rugman, and Verbeke, 1995). The original model created by Porter (1990) identified four endogenous dimensions that would address the most important aspects impacting an industry's competitiveness: factor conditions, demand conditions, related and supporting industries, and firm strategy, structure, and rivalry. The role of the government and of chance as exogenous dimensions must also be considered when forming the diamond model, as these indirectly shape the competitive environment.

Figure 1: Porter's Diamond Model

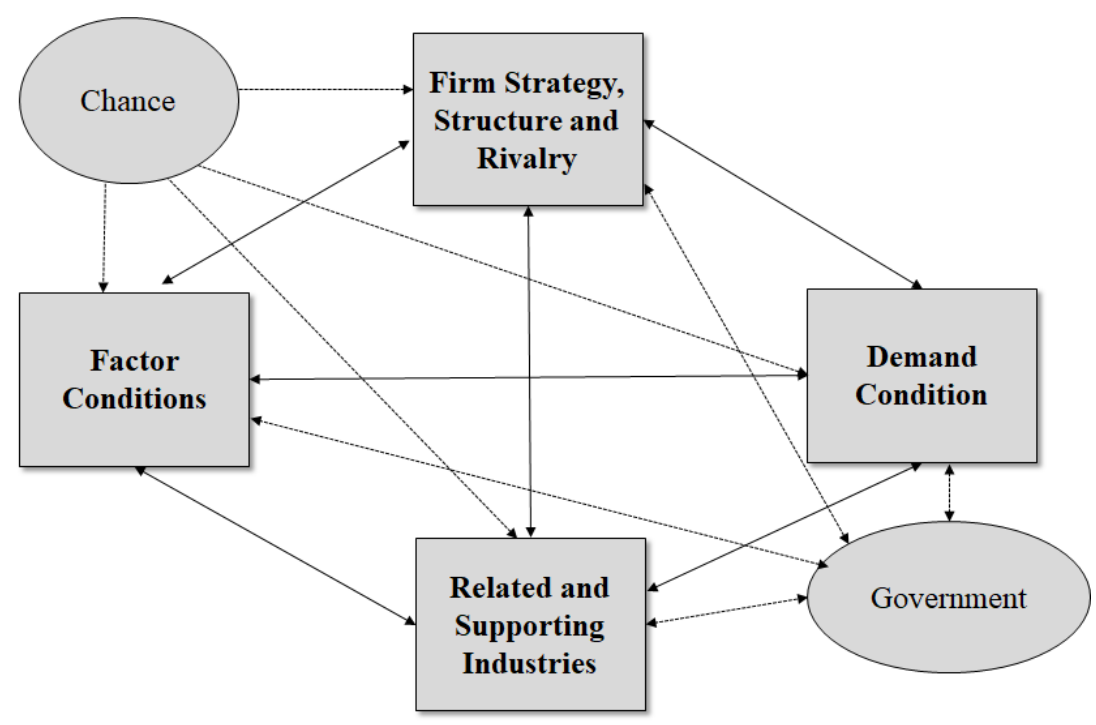

Source: Porter (1990)

In order to address an existing gap in Porter's analysis, Moon et al. (1995) extended the model to include an international diamond (dotted diamond) (Figure 2). This development aided comparisons between the domestic and international performance of industry to better determine strategies for improvement. Furthermore, whilst the original diamond model sees the role of the government as an exogenous factor, Moon, Rugman, and Verbeke $(1995,1998)$ argued for the large impact that policies created by the 
government can have on the level of competitive advantage that a nation can experience. To address this, this study incorporated a deeper analysis of the institutional context and government policies of both countries but did not analyze the impact of chance on the industry.

Figure 2: The Generalized Double Diamond Model

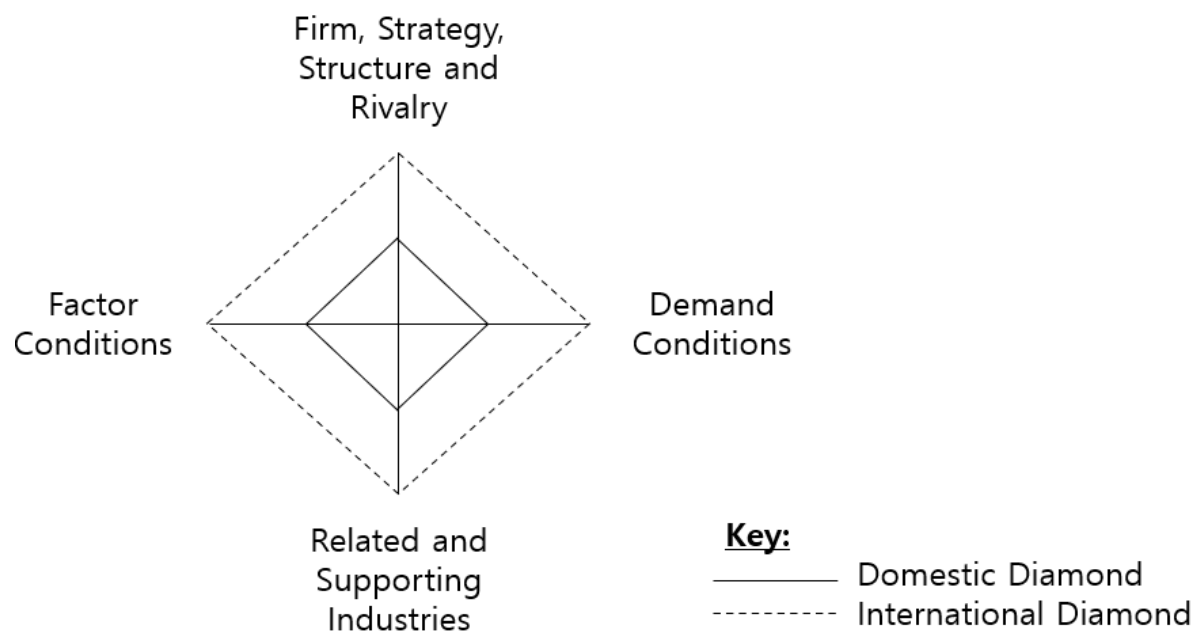

Source: Moon et al. (1995)

\section{METHODS}

\section{Data}

This study sought to determine which factors have been impacting the level of domestic and international competitiveness of the Korean and Japanese Pharmaceutical industry in recent years. Government level and firm-level data were utilized as statistical proxy variables to form a competitiveness index for each determinant needed to shape the domestic and international diamond models. Extracting the factors outlined in previous research into the pharmaceutical industry and that of other research applying the GDDM, the study operationalized 32 proxy variables. Table 2 (see APPENDIX) outlines the data sources and related research of the selected proxy variables. 
Where possible, variables specific to the pharmaceutical industry were utilized. Where data was unavailable, country-level values were then taken instead. For clarification purposes, industry-level variables have been labeled as (il), and country-level data is labeled as (cl). All listed variables were calculated as a three-year average and were predominantly within the timeframe of 2017 to 2019 to ensure that conditions were comparable and would not be impacted by unaccounted for factors from other years. However, some variables implemented data from earlier time points, namely 2015 and 2016, as these were the most recently published figures that could be attained whilst the study was being conducted.

\section{Variables}

\section{Factor conditions}

Factor conditions are production factors that are split into both basic and advanced and take into account physical, human, and capital resources (Porter, 1990). The pharmaceutical industry is dependent on a highly-skilled workforce who seek adequate wages in compensation for their labor (Suresh and Krishnaraj, 2015). Thus, to take this into consideration, the average total wage in US dollars was utilized from the OECD. As outlined by Cho and Moon (2010), and Olmeda and Sosa Varela (2012) it is important to consider the productivity of workers and therefore the Annual growth rate of output per worker expressed as a percentage was selected. When looking at basic international factors, it was important to look at the Outbound rate of FDI. As industry-specific FDI values could not be found that was comparable in range or calculation method for both Japan and Korea, it was necessary to use country-level data. Following Cho and Moon (2010), the second chosen factor is the outbound FDI growth rate index that factors in the level of growth that has occurred from 2017 to 2019.

The pharmaceutical sector is highly dependent on R\&D intensity as the industry depends on a continued supply of newly developed drugs being brought onto the market. To demonstrate the level of $R \& D$ expenditure occurring in the industry by businesses, Business enterprise expenditure on R\&D (BERD) in the pharmaceutical industry from 2016 to 2018 was selected from the OECD's ANBERD database. Song and Leker $(2018,169)$ argued that "firms with higher R\&D (research and development) expenditures have a tendency to greater external exploitation of technological knowledge than firms with low R\&D spending", and therefore a higher level of BERD would be indicative of more competitive firms. In addition, as both South Korea and Japan have thrived economically because of the availability of a highly skilled workforce over natural resources, the amount of R\&D 
personnel per million inbabitants from the UNESCO Institute for statistics was selected to demonstrate the quantity of talent that is available in the domestic market. For the international diamond, inbound FDI and the inbound FDI growth rate index were selected utilizing data from the UNCTAD database, in accordance with the works of several authors (Cho and Moon, 2013; Shabaninejad et al., 2014; Galović, 2015; Liu and Hsu, 2009; Moon and Lee, 2004; Molendowski and Zmuda, 2013; Cho and Moon, 2010).

Table 3: Variables for factor conditions

\begin{tabular}{|c|c|c|c|c|c|c|}
\hline \multirow[t]{2}{*}{ Factor } & \multirow[t]{2}{*}{ Market } & \multirow{2}{*}{$\begin{array}{l}\text { Sub- } \\
\text { Factor }\end{array}$} & \multirow[t]{2}{*}{ Proxy Variable } & \multicolumn{2}{|c|}{ Data Value } & \multirow[t]{2}{*}{ Measurement } \\
\hline & & & & Japan & Korea & \\
\hline \multirow[t]{8}{*}{$\begin{array}{c}\text { Factor } \\
\text { Conditions }\end{array}$} & Domestic & Basic & $\begin{array}{l}\text { Average Wage } \\
\text { (cl) 2017- } 2019\end{array}$ & $38,298.33$ & $40,885.67$ & $\begin{array}{l}3 \text { year average } \\
2017-19 \\
\text { USD\$ per hour }\end{array}$ \\
\hline & & & $\begin{array}{l}\text { Annual growth } \\
\text { rate of output } \\
\text { per worker (cl) } \\
2017-2019\end{array}$ & 0.30 & 2.00 & $\begin{array}{c}3 \text { year average } \\
2017-19, \text { annual } \\
\text { growth rate } \%\end{array}$ \\
\hline & & Advanced & $\begin{array}{c}\text { R\&D } \\
\text { expenditure (il) } \\
\text { 2016-2018 }\end{array}$ & $13,381.14$ & $1,652.28$ & $\begin{array}{c}3 \text { year, 2016-2018, } \\
\text { US\$ Mil, PPP, } \\
\text { BERD }\end{array}$ \\
\hline & & & $\begin{array}{l}\text { R\&D personnel } \\
\text { p/mil pop }(\mathrm{cl}) \\
\text { 2016-2018 }\end{array}$ & $6,954.96$ & $9,263.78$ & $\begin{array}{l}3 \text { year average } \\
\text { 2016-2018, p/mil } \\
\text { inhabitants }\end{array}$ \\
\hline & International & Basic & $\begin{array}{l}\text { Outbound FDI } \\
\text { (cl) 2017-2019 }\end{array}$ & 178,164 & 35,940 & $\begin{array}{l}3 \text { year average } \\
2017-19 \text {, US\$mil }\end{array}$ \\
\hline & & & $\begin{array}{l}\text { Outbound FDI } \\
\text { growth rate } \\
\text { index }(\mathrm{cl}) 2017- \\
2019\end{array}$ & $20,013.49$ & 506.91 & $\begin{array}{c}3 \text { year average } \\
2017-19, \text { FDI * } \\
\text { growth rate }\end{array}$ \\
\hline & & Advanced & $\begin{array}{l}\text { Inbound FDI } \\
\text { (cl) 2017-2019 }\end{array}$ & $11,795.67$ & $13,554.00$ & $\begin{array}{l}3 \text { year average } \\
2017-19 \text {, US\$mil }\end{array}$ \\
\hline & & & $\begin{array}{l}\text { Inbound FDI } \\
\text { growth rate } \\
\text { index }(\mathrm{cl}) 2017- \\
2019\end{array}$ & $1,162.26$ & $-2,186.94$ & $\begin{array}{l}3 \text { year average } \\
2017-19, \text { FDI * } \\
\text { growth rate }\end{array}$ \\
\hline
\end{tabular}




\section{Demand conditions}

Demand conditions demonstrate the quality and quantity of demand in the market for the products proin total or services of an industry by looking at the scale and sophistication of the consumer in the market. For the domestic diamond, Pharmaceutical spending, and The Total Sales as a percentage of GDP were selected. Scale is also important in the international context, and therefore, the market share of Korean and Japanese pharmaceutical industries as a percentage of the world market and total value of exports was utilized. In the pharmaceutical industry, consumption trends can shape production and investment flow into either niche therapeutic areas or incentivize firms to enter into the generic pharmaceutical segment. Therefore, the Market sophistication Index and GDP per capita were utilized in accordance with Cho and Moon (2010) and Vu and Pham (2016). To calculate the international sophistication of demand for the Japanese and South Korean pharmaceutical industry, the proxy variables used were the number of countries for pharmaceutical exports, and the percentage of exports without the top 3 countries. As Cho and Moon (2010) and Moon et al. (1998) argued, it's important to factor in the number of exports that go to countries beyond the top 3 destinations. If the industry's exports are dependent on a limited amount of foreign countries, the export markets and international demand are considered to be neither diversified, nor sophisticated (Moon et al., 1998).

\section{Related and supporting industries}

Shared technology, innovation and information flow between industries can result in huge advantages for downstream industries, and as such it is important to consider related and supporting industries when analyzing the competitiveness of any industry (Jin and Moon, 2006). The chosen measurements for the domestic hard infrastructure are the ICT development index, and the health infrastructure index. ICT infrastructure is an important indicator as delivery and research processes in the industry are progressively becoming dependent on technologies that have shaped Industry 4.0 such as AI and big data. The healthcare infrastructure is necessary to help support clinical trials by way of patient access, medical sophistication, and supporting research interests (PharmaBoardoom, 2019) but also ensures the effective administration of pharmaceutical products. To address the international competitiveness of these supporting and related industries, medical equipment and high technology export values were utilized. The readiness of foreign markets to consume these South Korean and Japanese products are indicative of international consumer 
A GENERALIZED DOUBLE DIAMOND APPROACH TO THE GLOBAL COMPETITIVENESS OF THE PHARMACEUTICAL INDUSTRY

Table 4: Variables for demand conditions

\begin{tabular}{|c|c|c|c|c|c|c|}
\hline \multirow{2}{*}{$\begin{array}{c}\text { Fact } \\
\text { or }\end{array}$} & \multirow{2}{*}{$\begin{array}{c}\text { Mark } \\
\text { et }\end{array}$} & \multirow{2}{*}{$\begin{array}{l}\text { Sub- } \\
\text { Factor }\end{array}$} & \multirow[t]{2}{*}{ Proxy Variable } & \multicolumn{2}{|c|}{ Data Value } & \multirow[t]{2}{*}{ Measurement } \\
\hline & & & & Japan & Korea & \\
\hline \multirow{9}{*}{ 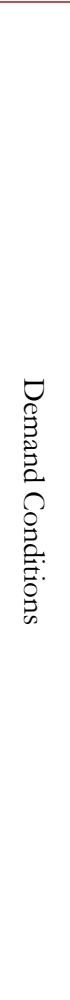 } & & Size & $\begin{array}{c}\text { Pharmaceutical } \\
\text { Spending (il) 2015- } \\
2017\end{array}$ & 18.86 & 20.64 & $\begin{array}{l}3 \text { year average } \\
2015-17, \% \text { of } \\
\text { health spending }\end{array}$ \\
\hline & $\underset{\wp}{\bigoplus}$ & & $\begin{array}{c}\text { Total Sales as } \\
\text { percentage of } \\
\text { GDP (il) } 2016- \\
2018\end{array}$ & 1.25 & 1.48 & $\begin{array}{c}3 \text { year average, } \\
2016-18, \% \text { of } \\
\text { GDP }\end{array}$ \\
\hline & 莒. & Quality & $\begin{array}{c}\text { Market } \\
\text { sophistication } \\
\text { index (cl) 2016- } \\
2018\end{array}$ & 65.96 & 61.34 & $\begin{array}{c}3 \text { year average } \\
\text { 2016-2018 } \\
\text { index, /100 }\end{array}$ \\
\hline & \multirow{6}{*}{ 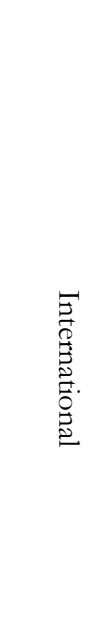 } & \multirow{6}{*}{ Quality } & $\begin{array}{c}\text { GDP/capita (cl) } \\
2017-2019\end{array}$ & $41,842.27$ & $42,020.67$ & $\begin{array}{c}3 \text { year average } \\
2017-19,\end{array}$ \\
\hline & & & $\begin{array}{l}\text { Share of World } \\
\text { Market (il) 2016- } \\
2018\end{array}$ & 7.88 & 1.94 & $\begin{array}{c}3 \text { year average } \\
2016-18\end{array}$ \\
\hline & & & $\begin{array}{c}\text { Export Value (il) } \\
2017-2019\end{array}$ & $209,564,715.67$ & $120,262,637.33$ & $\begin{array}{c}3 \text { year average } \\
2017-19, \text { US }\end{array}$ \\
\hline & & & & & & $\begin{array}{c}\text { Millions (UN } \\
\text { COMTRADE) }\end{array}$ \\
\hline & & & $\begin{array}{c}\text { Number of } \\
\text { Country for } \\
\text { Pharma exports(il) } \\
2017-2019\end{array}$ & 77 & 132 & $\begin{array}{c}3 \text { year average } \\
2017-19, \text { total } \\
\text { number }\end{array}$ \\
\hline & & & $\begin{array}{c}\text { Percentage of } \\
\text { Export without } \\
\text { top } 3 \text { (il) } 2017- \\
2019\end{array}$ & 45.82 & 60.16 & $\begin{array}{c}3 \text { year average } \\
2017-19, \%\end{array}$ \\
\hline
\end{tabular}

confidence in products from these countries.

In terms of soft innovation infrastructure, the number of domestically granted $A 61$ (pharmaceuticals under the IPC class system) patents and domestically published academic articles in pharmacology, toxicology, and pharmacentics were selected as proxy variables. To determine the level of international competitiveness, the Scimago journal and country rank in pharmaceutical science, and the total number of granted patents at the five IP offices (the CNIPA, EPO, JPO, KIPO, and USPTO) were selected. 
Table 5: Variables for related and supporting industries

\begin{tabular}{|c|c|c|c|c|c|c|}
\hline \multirow[t]{2}{*}{ Factor } & \multirow[t]{2}{*}{ Market } & \multirow{2}{*}{$\begin{array}{l}\text { Sub- } \\
\text { Factor }\end{array}$} & \multirow[t]{2}{*}{ Proxy Variable } & \multicolumn{2}{|c|}{ Data Value } & \multirow[t]{2}{*}{ Measurement } \\
\hline & & & & Japan & Korea & \\
\hline \multirow{12}{*}{ 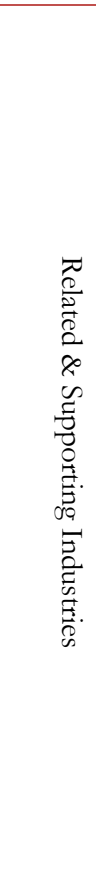 } & \multirow{6}{*}{ 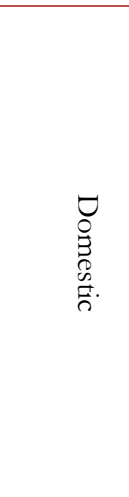 } & \multirow{6}{*}{ 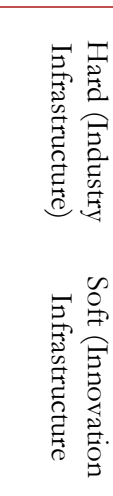 } & $\begin{array}{c}\text { ICT development } \\
\text { index (cl) 2015- } \\
2017\end{array}$ & 8.41 & 8.86 & $\begin{array}{c}3 \text { year average } \\
2015-17 \text { index } / 10\end{array}$ \\
\hline & & & $\begin{array}{c}\text { Health } \\
\text { Infrastructure } \\
\text { index (cl) 2017- } \\
2019\end{array}$ & 7.54 & 7.46 & $\begin{array}{c}3 \text { year average } \\
2017-19, \text { index } / 10\end{array}$ \\
\hline & & & Domestically & 9,378 & 5,252 & 3 year average \\
\hline & & & $\begin{array}{c}\text { granted patents (il) } \\
2015-2017\end{array}$ & & & $\begin{array}{c}2015-7 \text {, indiv unit, } \\
\text { by A61 class }\end{array}$ \\
\hline & & & Domestically & 2,520 & 3,799 & 3 year average \\
\hline & & & $\begin{array}{l}\text { published academic } \\
\text { articles (il) 2017- } \\
2019\end{array}$ & & & 2017-19, indiv unit \\
\hline & \multirow{6}{*}{ 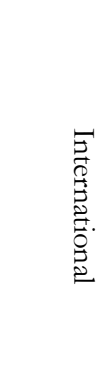 } & \multirow{3}{*}{ 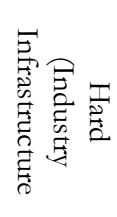 } & $\begin{array}{l}\text { Medical } \\
\text { Equipment export } \\
\text { (il) } 2017-2019\end{array}$ & $5,188,859,404$ & $1,770,338,470$ & $\begin{array}{l}3 \text { year average, } \\
2017-19, \text { US\$ }\end{array}$ \\
\hline & & & High Technology & 107.16 & 171.01 & 3 year average, \\
\hline & & & $\begin{array}{l}\text { Exports (cl) 2017- } \\
2019\end{array}$ & & & $\begin{array}{l}\text { 2017-19, (current } \\
\text { US\$ Billions) }\end{array}$ \\
\hline & & \multirow{3}{*}{ 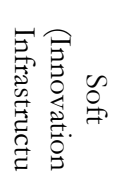 } & Scimago Ranking & $1,489.33$ & 961.67 & 3 year Average \\
\hline & & & (cl) 2017-2019 & & & $\begin{array}{l}\text { 2017-19, Total } \\
\text { docs }\end{array}$ \\
\hline & & & $\begin{array}{l}\text { Granted Patents } \\
\text { (il) 2015-2017 }\end{array}$ & 13,519 & 6,313 & $\begin{array}{c}3 \text { year average } \\
2015-17\end{array}$ \\
\hline
\end{tabular}

Firm strategy, structure, and rivalry

The final variable, firm strategy, structure, and rivalry, depicts the conditions that are determining the development, management, and degree of rivalry between firms. In terms of the domestic determinants, the intensity of local competitors and the number of pharmacentical manufacturers were chosen. To maximize the effectiveness of R\&D programs, shorten drug development and commercialization timelines, pharmaceutical companies are seeking to sophisticate their manufacturing and distribution processes. Therefore, this study implements sophisticated production processes as suggested by Olmeda and Sosa Varela (2012). The final variable, the social responsibility of business leaders, takes into account cultural factors that will attract the necessary talent into the industry as per Moon and Yu (2004) and Cho and Moon (2010). For countries like South Korea and Japan who are dependent on a strong innovation ecosystem, insufficient talent acquisition and retainment will be largely 
detrimental to local entrepreneurship and will hinder the growth of the pharmaceutical industry (Schwab, 2019).

Looking at the international factors, control of international distribution indicates the extent to which domestic firms own and control marketing and international distribution operations overseas. The number of clinical trials listed at WHO ICTRP was selected as it is indicative of the ability and the attractiveness of a country's clinical trials environment from an international perspective (Ribbink, 2013). In terms of strategy and structure, the ranking of the world's best-performing CEO and image abroad was chosen as international variables that demonstrate whether or not Korean and Japanese companies are receiving international recognition and are thus attractive for potential talent and investors.

Table 6: Variables for firm strategy, structure and rivalry

\begin{tabular}{|c|c|c|c|c|c|c|}
\hline \multirow[t]{2}{*}{ Factor } & \multirow[t]{2}{*}{ Market } & \multirow{2}{*}{$\begin{array}{l}\text { Sub- } \\
\text { Factor }\end{array}$} & \multirow[t]{2}{*}{ Proxy Variable } & \multicolumn{2}{|c|}{ Data Value } & \multirow[t]{2}{*}{ Measurement } \\
\hline & & & & Japan & Korea & \\
\hline $\begin{array}{l}\text { Firm } \\
\text { Strategy, } \\
\text { Structure }\end{array}$ & \multirow[t]{4}{*}{ Domestic } & \multirow[t]{2}{*}{ Rivalry } & $\begin{array}{c}\text { Intensity of local } \\
\text { competitors (cl) 2015-2017 }\end{array}$ & 6.20 & 5.90 & $\begin{array}{l}3 \text { year average } \\
2015-2017 \text {, } \\
\text { score } / 7\end{array}$ \\
\hline $\begin{array}{c}\& \\
\text { Rivalry }\end{array}$ & & & $\begin{array}{c}\text { Number of pharmaceutical } \\
\text { manufacturers(il) 2015- } \\
2017\end{array}$ & 301 & 615 & $\begin{array}{l}3 \text { year average } \\
2015-2017\end{array}$ \\
\hline & & \multirow[t]{2}{*}{$\begin{array}{l}\text { Strategy } \\
\& \& \\
\text { Structure }\end{array}$} & $\begin{array}{c}\text { Social Responsibility of } \\
\text { Business Leaders (cl) 2017- } \\
2019\end{array}$ & 7.21 & 4.94 & $\begin{array}{l}3 \text { year average } \\
2017-19 \\
\text { index } / 10\end{array}$ \\
\hline & & & $\begin{array}{l}\text { Sophisticated production } \\
\text { process(cl) 2015-2017 }\end{array}$ & 6.40 & 5.20 & $\begin{array}{l}3 \text { year average } \\
2015-2017 \\
\text { score } / 7\end{array}$ \\
\hline & \multirow[t]{4}{*}{ International } & \multirow[t]{2}{*}{ Rivalry } & $\begin{array}{l}\text { Control of international } \\
\text { distribution(cl) 2015-2017 }\end{array}$ & 5.40 & 5.00 & $\begin{array}{c}3 \text { year average } \\
2015-2017 \\
\text { score } / 7\end{array}$ \\
\hline & & & $\begin{array}{c}\text { Number of clinical trials } \\
\text { listed at WHO ICTRP(cl) } \\
2017-2019\end{array}$ & 105 & 209 & $\begin{array}{c}3 \text { year average } \\
2017-19, \\
\text { number of trials }\end{array}$ \\
\hline & & \multirow[t]{2}{*}{$\begin{array}{c}\text { Strategy } \\
\& \\
\text { Structure }\end{array}$} & $\begin{array}{l}\text { Ranking of world's best } \\
\text { performing ceo (cl) 2017- } \\
2019\end{array}$ & 6 & 0 & $\begin{array}{c}3 \text { year average } \\
2017-19, \\
\text { number in list }\end{array}$ \\
\hline & & & $\begin{array}{l}\text { Image Abroad (cl) 2017- } \\
\qquad 2019\end{array}$ & 7.11 & 7.55 & $\begin{array}{c}3 \text { year average } \\
2017-19 \\
\text { index } / 10\end{array}$ \\
\hline
\end{tabular}

\section{RESULTS}


To create a scaled comparison between Korea and Japan, the study referenced the calculation method present in existing studies: Son (2014), Son and Yokoyama (2013), Jin and Moon (2006), Vu and Pham (2016), Moon, et al. (1998), Liu and Hsu (2009), CastroGonzáles (2016), Molendowski and ŻMuda, (2013), Moon and Yu (2004), Cho and Moon (2010, 2013), Moon (2000) and Moon and Lee (2004). For each proxy variable, an index value was calculated. The country with the highest value was awarded 100 . The country with the lower value was given an index value that reflected its size in relation to the other country. For example, to calculate the index values for Korea and Japan for Average Wage (chosen as a basic domestic factor condition), Korea received a value of 100. To calculate Japan's index value, it was then necessary to find Japan's average wage as a percentage of Korea's wage ((38298.33/40,885.67) x 100). The final index value for the average wage was therefore 100 percent for Korea, and 94 percent for Japan.

The competitiveness index was then calculated by finding the average of each $f$ actor category. What is important to note is that these calculations are purely illustrat ive and serve only for the purpose of building the diamond model. The below table (Table 13) summarizes the competitive indices awarded to each factor for the South Korean and Japanese pharmaceutical industries:

Table 8: Competitiveness index of the Diamond Model for the South Korean and

\begin{tabular}{|c|c|c|c|}
\hline Factor & Market & Japan & Korea \\
\hline \multirow[t]{2}{*}{ Factor Conditions } & Domestic & 71 & 78 \\
\hline & International & 97 & 31 \\
\hline \multirow[t]{2}{*}{ Demand Conditions } & Domestic & 94 & 98 \\
\hline & International & 84 & 71 \\
\hline \multirow[t]{2}{*}{ Related and Supporting Industries } & Domestic & 90 & 89 \\
\hline & International & 91 & 61 \\
\hline \multirow[t]{2}{*}{ Firm Strategy, Structure and Rivalry } & Domestic & 87 & 86 \\
\hline & International & 86 & 73 \\
\hline
\end{tabular}

To visualize the results, the indices were then used to create both a domestic and an international diamond figure. The international diamond takes into account the existing 
values of the domestic market, and therefore was constructed by combining both domestic and international indices for each determinant (Moon et al., 1998).

According to the results of the study, South Korea's domestic diamond was larger than Japan surpassing it in two of the four determinants: factor and demand conditions. In terms of domestic demand, South Korea outperformed Japan across all variables bar market sophistication index (Figure 3), showing that the pharmaceutical market is already contributing more to the country's economy than Japan's own industry is. As is visible in Figure 3 and from Table 9, South Korea and Japan only had a one percent difference in terms of the competitiveness of related and supporting industries, and firm strategy, structure, and rivalry, showing that neither country has a substantial level of competitiveness in those factors over the other.

Figure 3: Domestic Diamond of the South Korean and Japanese pharmaceutical industries

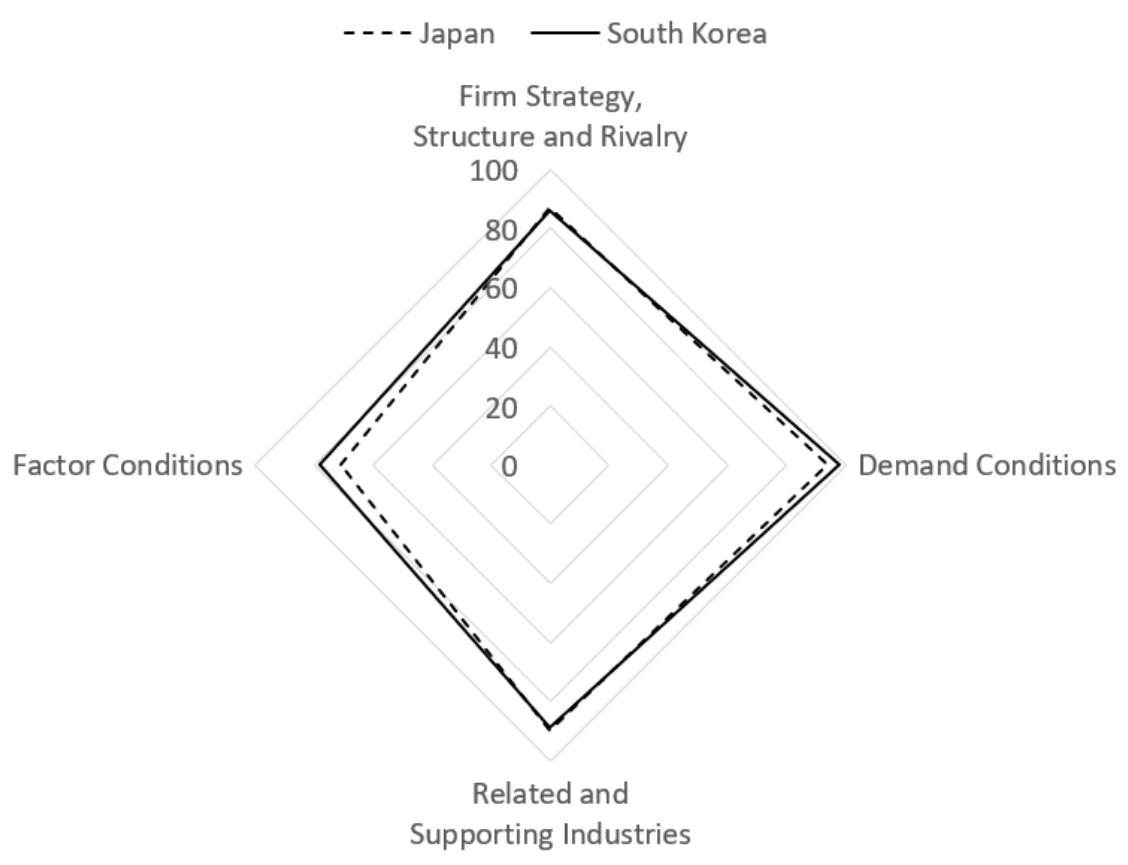

\section{DISCUSSION}




\section{The importance of internationalization for industrial competitiveness}

When looking at the International diamond model (Figure 4), Japan's pharmaceutical industry is shown to be more competitive across all parameters than South Korea. Moreover, the shape of South Korea's international diamond reflects similar findings made by Moon et al. (1998) whereby it was found to be relatively similar to its domestic diamond, showing that its overall competitiveness is not being supported by its international activities. Firstly, in line with the conclusion made by Park and Lee, South Korea was found to have a closed innovation system that utilized its domestic knowledge stock for new knowledge creation as its patents and academic research was more dependent on local knowledge sources and not international collaboration (Park and Lee, 2020). Moreover, in terms of a firm, strategy, structure, and rivalry, it is interesting to see that even though South Korea has almost double the number of pharmaceutical manufacturers that Japan has (615 and 301 respectively), they are not as well-known abroad or viewed as favorably as their Japanese competitors. Though they might be initiating international clinical trials, Japanese companies are outperforming their Korean counterparts in terms of a higher perceived level of control of international distribution, as well as having some of the world's best-performing CEOs. South Korea's weak position in Factor conditions also demonstrates that South Korea has not conducted as much Outbound FDI as Japan. Though South Korea in fact attracted more inbound FDI than Japan, which will help it attract foreign capital and technology (Moon et al., 1998), the growth rate index for inbound FDI in the selected time frame was negative. It is also important to note that these FDI values were on a country level and therefore are representative of the nation's ability to attract FDI and not the industry specifically.

These results show that South Korea must focus on developing its multinational activities in order to secure the future success of its pharmaceutical industry. Japan's competitive advantage over South Korea in the pharmaceutical industry has been shown to be a result of South Korea's weaker international performance across all determinants, resting predominantly on factor conditions and related and supporting industries. Though South Korea's pharmaceutical industry is quickly gaining competitiveness domestically, and 


\section{Figure 4: International Diamond of the South Korean and Japanese pharmaceutical industries}

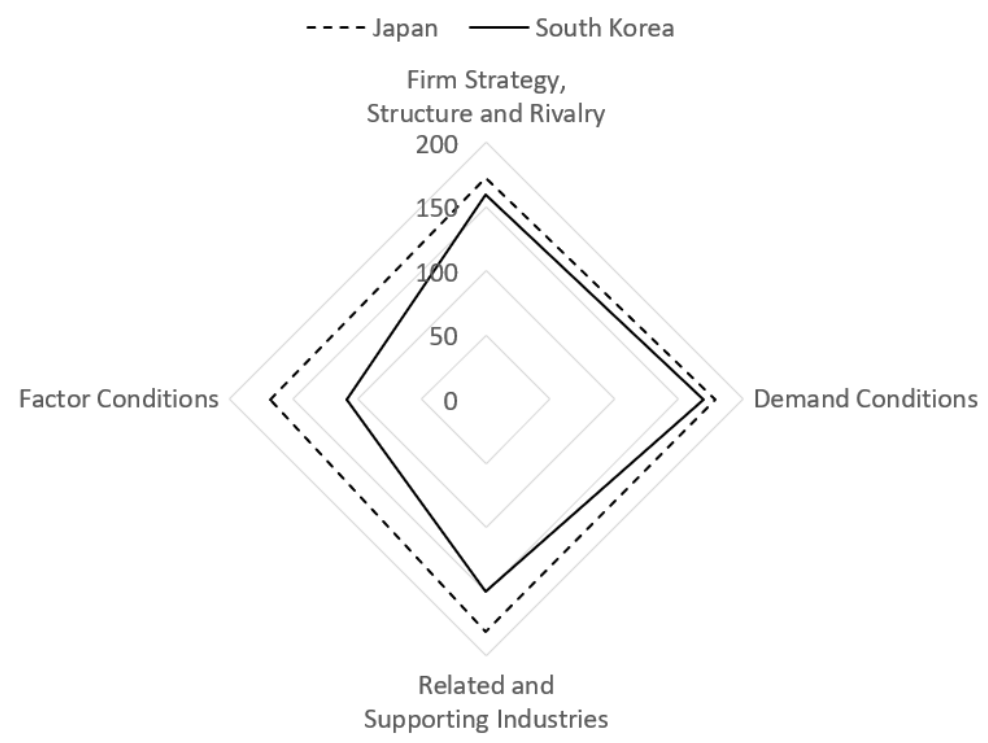

is already more competitive in 2 out of the 4 factors of the international diamond, the industry should be conscious of the sustained competitive loss it will incur if it does not address the two aforementioned weaker factors of its international diamond as these are causing the industry to be at a significant competitive disadvantage when compared to Japan.

\section{The role of government}

Though government policies were not assigned empirical values in the calculation of the diamond model, they nevertheless play an important role in the competitive advantage South Korea and Japan experience in their pharmaceutical industries. As outlined by Moon et al. (1998), the government's interventionist policies contributed greatly to Korea's economic development and the evolution of its domestic and international business environment. In terms of the pharmaceutical industry, Valverde argued that a pre-requisite for the industry to successfully generate returns on the large investments made was access to the global market (Valverde, 2016). Pease (2005) also argued for the central role that changes in the macro environment through regulatory reforms have had on increasing the competitiveness of pharmaceutical corporations and in driving their global expansion, particularly in the case of the Japanese industry. 
Japan's Ministry of Health, Labor, and Welfare (MHLW) has been implementing reforms to contain ever-rising health and pharmaceutical spending. With annual price reviews that favor the low production costs of Generic drugs, Japanese pharmaceutical companies are being forced to reevaluate their level of investment into branded drugs (BMIResearch, 2018) which is directly impacting the ability of R\&D focused pharmaceutical companies who rely on heavy investment to successfully innovate and discover new drugs. The government has therefore set up AMED (Japan Agency for Medical Research and Development), the PMD Act, and the SAKIGAKE Designation System to counteract the innovation drain resulting from generic usage and production and to ensure investment and interest in the Japanese market remains high. Through the implementation of the SAKIGAKE Designation System in 2014, drugs and device approvals were greatly accelerated, and review times were cut to a level comparable to the leading markets of the EU and US. Moreover, the scheme enabled the rapid authorization of drugs that were previously unapproved in Western countries, as well as expediting National Health Insurance reimbursement discussions and tax incentives (The Economist Intelligence Unit, 2020). In unison with the PMD Act, foreign companies are undertaking more collaborations than ever. This increased interest in cross-country cooperation is driving further open innovation projects, and carrying out mergers and acquisitions, and organized partnership conferences that attempt to harmonize pharmaceutical legislation, approval, and licensing regulations across countries (JPMA, 2015). As Asian countries are forecasted to have higher market growth rates than advanced countries, such collaborations expedite the entrance and launches of Japanese pharma products and companies, and therefore can help cover the market loss they would otherwise experience in the more established Western markets.

Japan has also been experiencing a decline in the number of highly trained specialists available to conduct the necessary clinical research as many have been disincentivised by Japan's traditionally risk-adverse business environment and lack of support for pharmaceutical start-ups (The Economist Intelligence Unit, 2020). Thus, the MHLW and AMED have been working together to provide training for scientists and biostatisticians (JPMA, 2015), and the KAKENHI Grants-in-Aid for Scientific Research programme was established to provide a budget for creative and pioneering research (JSPS, 2019).

Finally, to address the ever-changing technological landscape surrounding the pharmaceutical industry and encourage start-ups and small research institutes to conduct experimental research, the Japanese Government has sought to foster the integration of Big 
Data and AI in life science innovation by introducing the Next Generation Medical Infrastructure Law and through the 2019 Innovation Strategy.

The South Korean government is also the predominant source of funding for the country's healthcare system and the growing financial burden that is arising from increased demand and usage of medicines has led to the adoption of a discriminatory pharmaceutical pricing and reimbursement system that is projected to have a negative impact on the production of innovative and more expensive drugs. Since 2002, the Clinical Trial Authorization process was initiated by the government and has reduced clinical trial approval by ensuring cohesion between the Ministry of Food and Drug Safety (MFDS), institutional review boards, and ethics committees (KoNECT, 2017). Moreover, the MFDS is now a participant of both Inspection Co-operation Scheme and International Conference on Harmonization to standardize Korean manufacturing and quality management systems in line with the international community (KHIDI, 2018). More recently, the government renewed the Special Act on Pharmaceutical Industry Promotion and Support of the Pharmaceutical Industry to ensure that the industry continues to receive the support necessary for it to adopt new competitive technologies, increase employment, and become more internationally competitive (KHIDI, 2018).

Based on the results obtained using the GDD framework in this study, important implications for the South Korean Government can be drawn. In order to further improve the competitiveness of the industry, the Government should focus its efforts on nurturing the industry's openness to international cooperation and development. Given Japan's more international recognition, also supported by the results collected in this study, certain regulations or government schemes can be benchmarked and utilized to suggest as yet not fully explored regulatory opportunities for the Korean government. With prices of pharmaceutical products forecasted to continue dropping in order to account for ever-rising healthcare costs, the government should be wary of the innovation lag that such policy and pricing strategies have caused in Japan. Korean companies should also take heed of the vulnerability of Japan's smaller R\&D-based companies who weren't able to sustain their revenues with the introduction of policies that favored generics. Future policies should therefore strengthen public and private academic collaboration, and that between large and start-up/ spin-off companies, and support pioneering projects as the Kakenhi Grants-inAid scheme has done. The Korean government can also follow Japan's METI and recognize the risk-averse business environment present in Korea and lack of a strong international reputation in terms of business practices by improving listing systems for those who seek 
investment, as well as increasing communication channels and up-front investment conditions (The Economist Intelligence Unit, 2020). Similar to South Korea, the Japanese pharmaceutical industry had previously been one of the country's most close and domestically oriented industries. Korean companies should be wary of being over-reliant on domestically generated revenue as it may hinder their ability to already reinvest their pipelines in international activities upon the implementation of policies that will open up the industry to the international markets and competitors (Slater et al., 2008). The high level of outbound investment conducted by Japanese firms, and their international collaborations with other leading players on the global field proved to be a key contributor to Japan's higher level of international competitiveness when compared to Korea's pharmaceutical industry (Dwyer III, Jackson, and Omagari, 2020). Therefore, Korean officials should take note and ensure to increase funding, investment, and industry collaboration opportunities for firms inside and outside of Korea.

\section{CONCLUSION}

The purpose of this study was to determine the current level of competitiveness of the South Korean pharmaceutical industry and to measure its performance on a domestic and international front. In order to ascertain which areas South Korea should improve upon, the study utilized its global peer Japan as a benchmark for comparison. The study implemented the Generalized Double Diamond Model as a theoretical framework in order to present a holistic overview of the entire industry and within the context of the countries chosen for study. As argued in the Literature Review, this was a departure from existing literature, as previous research into the industry did not seek to create a comprehensive snapshot of the industry but merely analyzed the impact of individual factors on the competitiveness of the countries analyzed. In addition, previous literature had neglected to compare the countries chosen in this study, and so this study has helped further the existing analysis of the pharmaceutical industry by expanding the understanding of the South Korean and Japanese pharmaceutical markets.

As shown in the results section, South Korea and Japan have favorable domestic conditions to support the growth of their pharmaceutical market, but Japan is already seen to be less competitive than South Korea. This can be attributed to a lagging output growth rate, reduced numbers of domestically published articles, and from a demand perspective, the contribution of pharmaceutical sales to the economy's overall GDP. However, Japan 
outcompetes South Korea in terms of multinational activities and has therefore been able to sustain a global pharmaceutical competitive edge. In particular, South Korea must focus on supporting both outbound and inbound investment in the pharmaceutical industry to ensure that it can be globally competitive.

As South Korea looks to ensure the sustained performance of its knowledge-based economy, and secure the health of its aging population, it is more important than ever that policies are put in place to strengthen the competitiveness of its pharmaceutical industry. South Korea's economic growth, innovation capacity, and the public's accessibility to necessary medicine are likely to be compromised in the future if its pharmaceutical industry does prove to be competitive enough. If South Korea, therefore, wishes to surpass global peers like Japan on the global market, it must seek to address the leaks in its competitiveness as identified in this study. Policy recommendations presented in the study focus on addressing the limited international investment opportunities and incentives present in South Korea's pharmaceutical industry, as well as the need for innovative small companies and research institutes to be supported in the growth and internationalization strategies through education, funding, and open innovation opportunities.

\section{Limitations and futher study}

Due to data limitations and differences in statistical methodologies, some variables utilized data from different time periods and were not specific to the pharmaceutical industry. As some data was at the country level, it could therefore lead to inaccuracies and misrepresent the actual state of the pharmaceutical industry, particularly in the case of the FDI-related variables. In addition, though important conclusions could be drawn from the results obtained through this study, it is hard to validate all the findings without prior existing research for comparison. Future research should therefore seek out more reliable data related specifically to the pharmaceutical industry in order to derive more significant implications.

\section{ENDNOTE}

This paper is abstracted and improved from the author's master thesis. 


\section{REFERENCES}

Agrawal, M. 1999. The Effect of National Environment on Global Competitiveness: The Case of the Pharmaceutical industry. Journal of Transnational Management Development 4 (2): $27-48$

Bergman, A. 2006. FDI and spillover effects in the Indian pharmaceutical industry. Lund: Lund University

BMI Research. 2018. Asia Investment Opportunities in Pharmaceuticals: Risk/Reward Analysis. United Kingdom: BMI Research

Castro-Gonzáles, S., J. C. Peña-Vinces, and J. Guillen. 2016. The Competitiveness of LatinAmerican Economies: Consolidation of the Double Diamond Theory. Economic Systems 40 (3): 373-386.

Chen, Y. and K. Chang. 2010. The relationship between a firm's patent quality and its market value - The case of US pharmaceutical industry. Technological Forecasting \& Social Change 77 (1): 20-33.

Cho, D. S. and H. C. Moon. 2013. From Adam Smith To Michael Porter. World Scientific Publishing Company, 7

Cho, D. S. and H. C. Moon. 2010. National and Industry Competitiveness: Evaluation Model and Analytical Method. Seoul: The Institute for Industrial Policies (IPS)

Chung, H., S. Eum, and C. Lee. 2019. Firm Growth and R\&D in the Korean Pharmaceutical Industry. Sustainability (Basel, Switzerland) 11 (10): 28-65.

Cornell INSEAD WIPO. 2020. Market Sophistication, Normalized Score (Using Min-Max

Normalization Into 0-100 Range). Global Innovation Index. https://www.globalinnovationindex.org/analysis-indicator

Dwyer III, J. R., K. Jackson, and T, Omagari. 2020. M\&A Report 2020: Japan, IFLR. https://www.iflr.com/article/b1lmx68ylbmqhm/mampa-report-2020-japan

The Economist Intelligence Unit Limited. 2020. Supporting an innovative life sciences ecosystem in Japan. Japan: The Economist intelligence unit.

Elsevier. 2020. Domestic Publications in Pharmacology, Toxicology and Pharmaceutics. Elsevier Scopus Database, https://www.scopus.com/

fiveIPoffices. 2019. Patents granted by IPC class and by country of origin at the IP Five

Offices https://www.fiveipoffices.org/statistics/statisticaldata/statisticaldata_index 
Fukao, K., K. Ikeuchi., Y. Kim, H. Kwon, and T. Makino. 2016. International Competitiveness: A Comparison of the Manufacturing Sectors in Korea and Japan. Seoul Journal of Economics 29 (1): 43-68.

Galović, T. 2015. The International Competitiveness of the Pharmaceutical Industry within 21 OECD countries. Ekonomski Vjesnik/ Econviews: Review of Contemporary Business, Entrepreneurship and Economic Issues 28 (1): 225-241.

Gambardella, A., L. Orsenigo, and F. Pammolli. 2000. Global Competitiveness in Pharmaceuticals: A European perspective. Report prepared for the Directorate General Enterprise of the European Commission: 1-95, https://www.rieti.go.jp/jp/events/bbl/data/Pammolli.pdf

Harvard Business Review. 2017;2018;2019. The Best Performing CEOs in the World. hbr.org/2010/01/the-best-performing-ceos-in-the-world

Harvard Business Review. 2018. Why the Pharmaceutical Industry is Booming in Japan. https://hbr.org/sponsored/2018/03/why-the-pharmaceutical-industry-is-boomingin-japan

ILO. 2020. Labour productivity, Annual growth rate (\%). https://ilostat.ilo.org/data/

IMD. 2020. Image abroad or branding. IMD World Competitiveness Online, https://worldcompetitiveness.imd.org/

IMD. 2020. Social Responsibility. IMD World Competitiveness Online, https://worldcompetitiveness.imd.org/rankings/wcy

IMD. 2020. Health Infrastructure. IMD World Competitiveness Online, https://worldcompetitiveness.imd.org/

IQVIA MIDAS. 2019. Top 10 Pharmaceutical Markets Worldwide: 2019 in Pharmaceutical Trends, $\quad$ https://www.iqvia.com/-/media/iqvia/pdfs/canada/2019trends/top10worldwidesales_en_19.pdf?la=en\&hash=5B6D9922E053B42D9F2A1F D7A1883A87

Jin, B. H. and H. C. Moon. 2006. The Diamond Approach to the Competitiveness of Korea's Apparel Industry: Michael Porter and Beyond. Journal of Fashion Marketing and Management 10 (2): 195-208

JPMA. $2019 . \quad$ DATA BOOK, http://www.jpma.or.jp/about/issue/gratis/databook/2019/data/pdf/e_DB2019.pdf JPMA. 2015. JPMA Industry Vision 2025, Bringing Innovation in Drug Discovery to the World, http://www.jpma.or.jp/english/policies_guidelines/pdf/industry_vision2025.pdf 
JSPS. 2019. Grants-in-Aid for Scientific Research 2019: Creating New Knowledge- For shaping and transmitting World-leading Knowledge Assets, https://www.jsps.go.jp/english/e-grants/

Keyhani, S., S. Wang., P. Herbert., D. Carpenter, and G. Anderson. 2010. US Pharmaceutical Innovation in an International Context. American Journal of Public Health, 1971100 (6): 1075-1080.

KHIDI. 2018. Pharmaceutical and Biopharmaceutical Industry in Korea. Seoul: KHIDI

KHIDI. 2018. Korea Innovative Pharmaceutical Company. Seoul: KHIDI

KHIDI, 2018. Size and Market Trends in Pharmaceutical Industry in Korea (Unit: KRW Trillion, $\quad$ \%orea $\quad$ Pharmaceuticals. https://www.khidi.or.kr/board?menuId=MENU02288\&siteId=SITE00032

Kim, Y. and M. Lee. 2019. Korea: Thinking Big! Healthcare \& Life Science Review Korea, PharmaBoardroom

KoNECT. 2017. Start with Korea: The Right Place for Clinical Trials in Asia, https://www.konect.or.kr/upload/downfile/Start_with_Korea_2017.pdf

Ku, M. S. 2015. Recent Trends in Specialty Pharma Business Model. J Food Drug Anal. 23 (4): 595-608.

Kuwashima, K. 1999. Organizational Capabilities in Pharmaceutical Research and Development. Annals of Organizational Science, International Special Issue of Organizational Science (2015) 47 (5): 11-28

Lakner, Z., A. Kiss., J. Popp., Z. Zéman., D. Máté, and J. Oláh. 2019. From Basic Research to Competitiveness: An Econometric Analysis of the Global Pharmaceutical Sector. Sustainability (Basel, Switzerland) 11 (11): 3125.

Laurens, P., C. Le Bas, A. Schoen. 2019. Worldwide IP Coverage of Patented Inventions in Large Pharma Firms: to What Extent Do the Internationalisation of R\&D and Firm Strategy Matter? International Journal of Technology Management 80 (3-4): 177-211.

Liu, D. and H. Hsu. 2009. An International Comparison of Empirical Generalized Double

Diamond Model Approaches to Taiwan and Korea. Competitiveness Review: An International Business Journal 19 (3): 160-174.

Ministry of Food and Drug Safety. 2019. [19' MFDS] Korea Food \& Drug Statistical Yearbook

https: / $/$ www.mfds.go.kr/brd/m_371/view.do?seq $=30718 \& \operatorname{srchFr}=\& \operatorname{srchTo}=\&$ srch

Word $=\& \operatorname{srch} T \mathrm{p}=\& \mathrm{itm} \_\mathrm{s}$

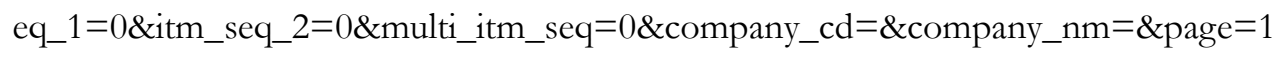


Mishra, P. and N. Jaiswal. 2017. Impact of Mergers and Acquisitions on Firms' Export Competitiveness. South Asia Economic Journal 18 (1):1-20.

Molendowski, E. and M. ŻMuda. 2013. Changes In Competitiveness Among The Visegrad Countries After Accession to The European Union: A Comparative Analysis Based on A Generalized Double Diamond Model. Comparative Economic Research 16 (4): 121-153.

Moon, H. C., A. Rugman, and A. Verbeke. 1998. A generalized double diamond approach to the international competitiveness of Korea and Singapore". International Business Review 7 (2): 135-50.

Moon, H. C., A. Rugman, and A. Verbeke. 1995. The generalized double diamond approach to the international competitiveness. Rugman, A., Van Den Broeck, J. and Verbeke, A. (Eds), Research in Global Strategic Management 5: 97-114.

Moon, H. C. and D. Lee. 2004. The Competitiveness of Multinational Firms: A Case Study of Samsung Electronics and Sony. Journal of International and Area Studies 11 (1): 1-21.

Moon, H. C. 2000. Competitiveness of the Internet Industry in Korea and Japan: Case Studies of Korea Telecom Freetel and NTT DoCoMo. Journal of International and Area Studies 7 (2): 37-52. Retrieved May 19, 2020, from www.jstor.org/stable/43111424

Moon, H. C. and Y. L. Yu. 2004. The Competitiveness of China's Telecommunications Industry before and after China's Accession to the WTO. Global Economic Review 33 (2): 79-98.

Nagatani, T., M. Raviscioni, and A. Sugahara. 2018. Change in the Japanese pharmaceutical market: Cradle of innovation or grave of corporate profits? Mckinsey, https://www.mckinsey.com/industries/pharmaceuticals-and medical-products/ourinsights/change-in-the-japanese-pharmaceutical-market-cradle-of-innovation-or grave-of-corporate-profits.

OECD. 2020. Gross Domestic Product (GDP) Total, US dollars/capita, 2015 - 2019, https://data.oecd.org/gdp/gross-domestic-product-gdp.htm

OECD. 2018. Health Policy Studies. Pharmaceutical Innovation and Access to Medicines, https://doi.org/10.1787/9789264307391-en Accessed 20/10/2020

OECD. 2020. Average wages (indicator). OECD Employment Outlook, https://data.oecd.org/earnwage/average-wages.htm

OECD. 2019. Business enterprise expenditure for pharmaceutical R\&D (BERD). Analytical Business Enterprise Research and Development (ANBERD) Database, https://doi.org/10.1787/888934018203 
OECD. 2019. Research and development in the pharmaceutical sector. Health at a Glance 2019: OECD Indicators, https://www.oecd-ilibrary.org//sites/4dd50c09en/1/2/10/5/index.html?itemId=/content/publication/4dd50c09en\&mimeType $=$ text $/$ html\&_csp_=82587932df7c06a6a3f9dab95304095d\&itemIGO $=$ oecd\&itemContent Ty pe $=$ book

OECD. 2020. Total Pharmaceutical Sales (Million US\$, purchasing power parity), https://stats.oecd.org/Index.aspx?DataSetCode=HEALTH_PHMC\#

Olmeda, G, and J C Sosa-Varela. 2012. Determinants of International Competitiveness in the Pharmaceutical Industry. ESIC Market Economic and Business Journal 43 (2): 371-385

Park, E. and A. Lee. 2020. Neighbours with different innovation patterns: the implications of industrial and FDI policy for the openness of local knowledge production. Transnational Corporations 27 (1).

Pease, S. 2005. Strategic Shift in Japanese Corporations: The Case of the Pharmaceutical Industry. 4th European Marketing Trends. Congress Paris 2005, http:/ /archives.marketing-trendscongress.com/2005/Materiali/Paper/Fr/PEASE_PALIWODA.pdf

PharmaBoardroom. 2019. Ahead in the race to become a preferred clinical research destination. Healthcare \& Life Sciences Review: Korea, https://www.cphi.com/content/dam/Informa/cphi/korea/en/2020/pdffiles/market-reports/HLN19CPK-SP Pharmaboardroom\%20Report.pdf

Pradhan, J P. 2006. Global Competitiveness of Indian Pharmaceutical Industry: Trends and Strategies, ISID Working Paper, (2006/05)

Porter, M. E. 1998. The Competitive Advantage of Nations: with a New Introduction. Harvard Business Review 1990: March-April.

Porter, M. E. 1990. The Competitive Advantage of Nations. New York: Free Press.

Ribbink, K. 2013. The Changing Face of South Korean Pharma. PharmaVoice, https://www.pharmavoice.com/article/south-korean-pharma/

Rugman, A. M. and A. Verbeke. 1990. Global Corporate Strategy and Trade Policy. London: Routledge.

Schwab, K. 2019. The Global Competitiveness Report 2015-16, 2016-17, 2017-18 Insight Report. World Economic Forum, http://www3.weforum.org/docs/gcr/20152016/Global_Competitiveness_Report_2015-2016.pdf

ScimagoLab. 2020. Scimago Journal \& Country Rank in Pharmaceutical Science, https://www.scimagojr.com/countryrank.php?category $=3003$ 
Shabaninejad, H., G. Mehralian., A. Rashidian., A. Baratimarnani, and H. R. Rasekh. 2014. Identifying and Prioritizing Industry-Level Competitiveness Factors: Evidence from Pharmaceutical Market. Daru 22 (1):35.

Slater, S., S. Paliwoda, and J. Slater. 2008. Strategic Inertia and the Japanese Pharmaceutical Industry. Multinational Business Review 16 (4): 1-23.

Son, M. 2014. A Comparative Analysis on the Competitiveness of the Korean, Chinese and Japanese Fashion Industries: The Generalized Double Diamond Model Approach. The Korean Society of Fashion Business 18 (6): 67-85.

Son, M. and K. Yokoyama. 2013. A Comparative Analysis on the Competitiveness of Korean and Japanese Fashion Industry by Applying Generalized Double Diamond Model." Asia Marketing Journal 15 (1): 57-81

Song, C. H. and J. Leker. 2019. Differentiation of innovation strategies based on pharmaceutical licensing agreements: Insight from Korean pharmaceutical firms, Technology Analysis \& Strategic Management 31 (2): 169-185.

Suresh, L. and R Krishnaraj. 2015. A Study on the Importance of Employee Retention in the Pharmaceutical Sector in India. International Journal of Pharmaceutical Sciences Review and Research 32 (19): 108-111.

UN Comtrade. 2020. Total Value of Pharmaceutical Exports (Millions, US\$), https:// comtrade.un.org/data/

UN Comtrade. 2020. Medical Instrument and appliance export to world. 2020 Medical Instrument and appliance export to world, https://comtrade.un.org/

UNCTAD. 2020. Foreign Direct Investment (FDI) Overview. World Investment Report 2020. Japan and Korea: Country Fact Sheets.

Unesco Institute for Statistics. 2020. Total R\&D personnel per million inhabitants, http://data.uis.unesco.org/Index.aspx?DataSetCode=SCN_DS

United Nations International Telecommunications Union. 2017. The ICT Development Index, https://www.itu.int/net4/ITU-D/idi/2017/index.html

Valverde, J. 2016. The globalization of medicines as a challenge for governments. Pharmaceuticals Policy and Law. 18: 19-29.

Vu, H T. and L. C. Pham. 2016. A dynamic approach to assess international competitiveness of Vietnam's garment and textile industry. SpringerPlus 5 (203).

The World Bank. 2020. High Technology Exports (current US\$ Billions), https://data.worldbank.org/indicator/TX.VAL.TECH.CD 
The World Bank. 2020. GDP, PPP (constant 2017 international \$), https:// data.worldbank.org/indicator/NY.GDP.MKTP.PP.KD?end=2019\&locations $=$ US-JP KR\&most_recent_year_desc $=$ true\&start $=1990 \& v i e w=$ chart

World Economic Forum. 2015; 2016; 2017. The Global Competitiveness Report (20152016, 2016-17, 2017-18), https://www.weforum.org/reports/the-globalcompetitiveness-report-2017-2018

WHO. 2017;2018; 2019. Number of clinical trials by year, country, WHO region and income group, WHO Global Observatory on Health R\&D.

WTO. 2020. Chapter IV: Shifting Patterns. Trade in World Trade Statistical Review 32-59.

WTO. 2020. The WTO's Pharma Agreement (based on L/7430, 1994), https://www.wto.org/english/tratop_e/pharma_ag_e/pharma_agreement_e.htm

WTO. 2019. Chapter II: Highlights of world trade. World statistical trade Review 6-15. 
A GENERALIZED DOUBLE DIAMOND APPROACH TO THE GLOBAL COMPETITIVENESS OF THE PHARMACEUTICAL INDUSTRY

APPENDIX

Table 2: Descriptive data for Diamond Variables

(including data source and related research)

\begin{tabular}{llccccc}
\hline Factor & Market & Sub-Factor & $\begin{array}{c}\text { Proxy } \\
\text { Variable }\end{array}$ & $\begin{array}{c}\text { Measureme } \\
\text { nt }\end{array}$ & Source & $\begin{array}{c}\text { Related } \\
\text { Studies }\end{array}$
\end{tabular}

\begin{tabular}{|c|c|c|c|c|c|c|}
\hline \multirow[t]{6}{*}{$\begin{array}{c}\text { Factor } \\
\text { Conditio } \\
\text { ns }\end{array}$} & \multirow[t]{4}{*}{ Domestic } & \multirow[t]{2}{*}{ Basic } & $\begin{array}{l}\text { Average Wage } \\
\text { (cl) 2017- } \\
2019\end{array}$ & $\begin{array}{c}3 \text { year } \\
\text { average } \\
2017-19 \text {, } \\
\text { USD\$ per } \\
\text { hour }\end{array}$ & $\begin{array}{c}\text { IMD world } \\
\text { competitiveness }\end{array}$ & $\begin{array}{l}\text { Vu and } \\
\text { Pham, } \\
\text { 2016; } \\
\text { Olmeda } \\
\text { and Sosa- } \\
\text { Varela, } \\
2012\end{array}$ \\
\hline & & & $\begin{array}{c}\text { Annual } \\
\text { growth rate of } \\
\text { output per } \\
\text { worker (cl) } \\
2017-2019\end{array}$ & $\begin{array}{c}3 \text { year } \\
\text { average } \\
2017-19, \\
\text { annual } \\
\text { growth } \\
\text { rate } \%\end{array}$ & ILO & $\begin{array}{l}\text { Cho and } \\
\text { Moon, } \\
\text { 2010; } \\
\text { Olmeda } \\
\text { and Sosa } \\
\text { Varela, } \\
2012\end{array}$ \\
\hline & & \multirow[t]{2}{*}{ Advanced } & $\begin{array}{c}\text { R\&D } \\
\text { expenditure } \\
\text { (il) } 2016-2018\end{array}$ & $\begin{array}{c}3 \text { year, 2016- } \\
2018, \\
\text { US\$ Mil, } \\
\text { PPP, BERD }\end{array}$ & $\begin{array}{l}\text { OECD } \\
\text { ANBERD } \\
\text { database }\end{array}$ & $\begin{array}{c}\text { Keyhani, } \\
\text { 2010; } \\
\text { Castro } \\
\text { Gonzales, } \\
\text { 2016; Liu } \\
\text { and Hsu, } \\
2009\end{array}$ \\
\hline & & & $\begin{array}{c}\text { R\&D } \\
\text { personnel } \\
\text { p/mil pop (cl) } \\
\text { 2016-2018 }\end{array}$ & $\begin{array}{c}3 \text { year } \\
\text { average } \\
2016-2018, \\
\mathrm{p} / \mathrm{mil} \\
\text { inhabitants }\end{array}$ & $\begin{array}{l}\text { Unesco } \\
\text { Institute for } \\
\text { Statistics }\end{array}$ & $\begin{array}{l}\text { Liu and } \\
\text { Hsu, 2009; } \\
\text { Son and } \\
\text { Yokoyama } \\
\text {,2013; } \\
\text { Cho and } \\
\text { Moon, } \\
2010\end{array}$ \\
\hline & \multirow[t]{2}{*}{$\begin{array}{c}\text { Internatio } \\
\text { nal }\end{array}$} & \multirow[t]{2}{*}{ Basic } & $\begin{array}{l}\text { Outbound } \\
\text { FDI (cl) 2017- } \\
2019\end{array}$ & $\begin{array}{c}3 \text { year } \\
\text { average } \\
2017-19 \text {, } \\
\text { US\$mil }\end{array}$ & UNCTAD & $\begin{array}{l}\text { Cho and } \\
\text { Moon, } \\
\text { 2013; } \\
\text { Galović, } \\
\text { 2015; Liu } \\
\text { and Hsu, } \\
\text { 2009; Cho } \\
\text { and Moon, } \\
2010\end{array}$ \\
\hline & & & $\begin{array}{l}\text { Outbound } \\
\text { FDI growth } \\
\text { rate index (cl) } \\
2017-2019\end{array}$ & $\begin{array}{c}3 \text { year } \\
\text { average } \\
2017-19, \\
\text { FDI }{ }^{*} \\
\text { growth rate }\end{array}$ & UNCTAD & $\begin{array}{l}\text { Cho and } \\
\text { Moon, } \\
2010\end{array}$ \\
\hline
\end{tabular}




\begin{tabular}{|c|c|c|c|c|c|c|}
\hline & & Advanced & $\begin{array}{l}\text { Inbound FDI } \\
\text { (cl) 2017-2019 }\end{array}$ & $\begin{array}{c}3 \text { year } \\
\text { average } \\
2017-19, \\
\text { US\$mil }\end{array}$ & UNCTAD & $\begin{array}{l}\text { Cho and } \\
\text { Moon, } \\
\text { 2013; } \\
\text { Shabaninej } \\
\text { ad et al., } \\
\text { 2014; } \\
\text { Galović, } \\
\text { 2015; Liu } \\
\text { and Hsu. } \\
\text { 2009; } \\
\text { Moon and } \\
\text { Yu, 2004; } \\
\text { Mol and } \\
\text { Zmuda, } \\
\text { 2013; Cho } \\
\text { and Moon, } \\
\text { 2010 }\end{array}$ \\
\hline & & & $\begin{array}{l}\text { Inbound FDI } \\
\text { growth rate } \\
\text { index }(\mathrm{cl}) \\
2017-2019\end{array}$ & $\begin{array}{c}3 \text { year } \\
\text { average } \\
2017-19, \\
\text { FDI } * \\
\text { growth rate }\end{array}$ & UNCTAD & $\begin{array}{l}\text { Liu and } \\
\text { Hsu, 2009; } \\
\text { Cho and } \\
\text { Moon, } \\
2010\end{array}$ \\
\hline \multirow[t]{7}{*}{$\begin{array}{l}\text { Demand } \\
\text { Conditio } \\
\text { ns }\end{array}$} & \multirow[t]{4}{*}{ Domestic } & Size & $\begin{array}{l}\text { Pharmaceutic } \\
\text { al Spending } \\
\text { (il) 2015-2017 }\end{array}$ & $\begin{array}{c}3 \text { year } \\
\text { average } \\
2015-17, \% \\
\text { of health } \\
\text { spending }\end{array}$ & OECD & $\begin{array}{l}\text { Keyhani, } \\
\text { 2010; } \\
\text { Castro- } \\
\text { Gonzales, } \\
2016\end{array}$ \\
\hline & & & $\begin{array}{l}\text { Total Sales as } \\
\text { percentage of } \\
\text { GDP (il) } \\
2016-2018\end{array}$ & $\begin{array}{c}3 \text { year } \\
\text { average, } \\
2016-18, \% \\
\text { of GDP }\end{array}$ & $\begin{array}{l}\text { export.gov/ } \\
\text { khidi.or.kr }\end{array}$ & $\begin{array}{c}\text { Moon and } \\
\mathrm{Yu}, 2004\end{array}$ \\
\hline & & Quality & $\begin{array}{c}\text { Market } \\
\text { sophistication } \\
\text { index }(\mathrm{cl}) \\
\text { 2016-2018 }\end{array}$ & $\begin{array}{c}3 \text { year } \\
\text { average } \\
2016-2018 \\
\text { index, } / 100\end{array}$ & $\begin{array}{c}\text { Cornell } \\
\text { INSEAD } \\
\text { WIPO, Global } \\
\text { Innovation } \\
\text { Index }\end{array}$ & $\begin{array}{l}\text { Cho and } \\
\text { Moon, } \\
2010\end{array}$ \\
\hline & & & $\begin{array}{l}\text { GDP/capita } \\
\text { (cl) 2017-2019 }\end{array}$ & $\begin{array}{c}3 \text { year } \\
\text { average } \\
2017-19\end{array}$ & OECD & $\begin{array}{l}\text { Vu and } \\
\text { Pham, } \\
2016\end{array}$ \\
\hline & \multirow[t]{3}{*}{$\begin{array}{l}\text { Internatio } \\
\text { nal }\end{array}$} & Size & $\begin{array}{l}\text { Share of } \\
\text { World Market } \\
\text { (il) } 2016-2018\end{array}$ & $\begin{array}{c}3 \text { year } \\
\text { average } \\
2016-18\end{array}$ & $\begin{array}{c}\text { OECD, } \\
\text { Worldbank }\end{array}$ & $\begin{array}{c}\text { Son and } \\
\text { Yokoyama } \\
\text {,2013 }\end{array}$ \\
\hline & & & $\begin{array}{l}\text { Export Value } \\
\text { (il) } 2017-2019\end{array}$ & $\begin{array}{c}3 \text { year } \\
\text { average } \\
\text { 2017-19, US } \\
\text { Millions } \\
\text { (UN } \\
\text { COMTRAD } \\
\text { E) }\end{array}$ & UN Comtrade & $\begin{array}{l}\text { Mol and } \\
\text { Zmuda, } \\
2013 \text { ( per } \\
\text { capita ) }\end{array}$ \\
\hline & & Quality & $\begin{array}{l}\text { Number of } \\
\text { Country for } \\
\text { Pharma } \\
\text { exports(il) } \\
2017-2019\end{array}$ & $\begin{array}{c}3 \text { year } \\
\text { average } \\
2017-19 \text {, } \\
\text { total number }\end{array}$ & UN Comtrade & $\begin{array}{l}\text { Cho and } \\
\text { Moon, } \\
2010\end{array}$ \\
\hline
\end{tabular}




\section{A GENERALIZED DOUBLE DIAMOND APPROACH TO THE GLOBAL}

COMPETITIVENESS OF THE PHARMACEUTICAL INDUSTRY

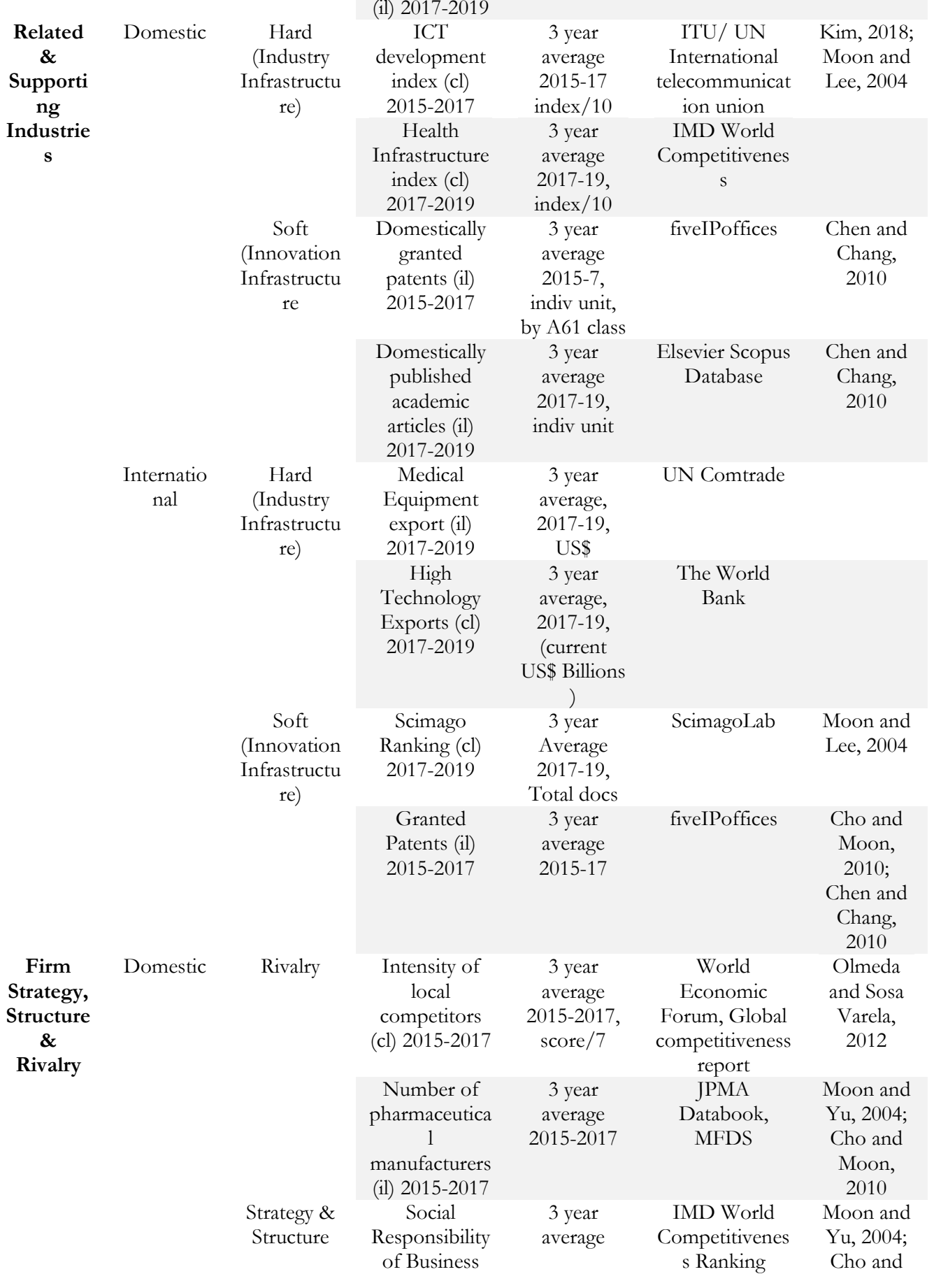

$\begin{array}{cccc}\begin{array}{c}\text { Percentage of } \\ \text { Export }\end{array} & \begin{array}{c}3 \text { year } \\ \text { average }\end{array} & \text { UN Comtrade } & \begin{array}{c}\text { Cho and } \\ \text { Moon, }\end{array} \\ \text { without top 3 } & 2017-19, \% & & 2010\end{array}$

2017-2019

velopment

ion union

IMD World

Infrastructure average Competitivene

index (cl) 2017-19,

2017-2019 index/10

Domestically 3 year

indiv unit,

y A61 class

academic

3 year

2017-19,

US\$

(current

S\$ Billions

3 year

Average

2017-19,

Cho and 


\begin{tabular}{|c|c|c|c|c|c|}
\hline & & $\begin{array}{l}\text { Leaders (cl) } \\
2017-2019\end{array}$ & $\begin{array}{l}\text { 2017-19, } \\
\text { index } / 10\end{array}$ & & $\begin{array}{c}\text { Moon, } \\
2010\end{array}$ \\
\hline & & $\begin{array}{l}\text { Sophisticated } \\
\text { production } \\
\text { process }(\mathrm{cl}) \\
2015-2017\end{array}$ & $\begin{array}{c}3 \text { year } \\
\text { average } \\
2015-2017, \\
\text { score } / 7\end{array}$ & $\begin{array}{c}\text { World } \\
\text { Economic } \\
\text { Forum, Global } \\
\text { competitiveness } \\
\text { report }\end{array}$ & $\begin{array}{l}\text { Olmeda } \\
\text { and Sosa } \\
\text { Varela, } \\
2012\end{array}$ \\
\hline \multirow[t]{4}{*}{$\begin{array}{c}\text { Internatio } \\
\text { nal }\end{array}$} & Rivalry & $\begin{array}{l}\text { Control of } \\
\text { international } \\
\text { distribution(cl } \\
\text { ) 2015-2017 }\end{array}$ & $\begin{array}{c}3 \text { year } \\
\text { average } \\
2015-2017, \\
\text { score } / 7\end{array}$ & $\begin{array}{c}\text { World } \\
\text { Economic } \\
\text { Forum, Global } \\
\text { competitiveness } \\
\text { report }\end{array}$ & $\begin{array}{l}\text { Olmeda } \\
\text { and Sosa } \\
\text { Varela, } \\
2012\end{array}$ \\
\hline & & $\begin{array}{c}\text { Number of } \\
\text { clinical trials } \\
\text { listed at } \\
\text { WHO } \\
\text { ICTRP }(\mathrm{cl}) \\
2017-2019\end{array}$ & $\begin{array}{c}3 \text { year } \\
\text { average } \\
2017-19 \text {, } \\
\text { number of } \\
\text { trials }\end{array}$ & WHO ICTRP & $\begin{array}{c}\text { Shabaninej } \\
\text { ad et al., } \\
2014\end{array}$ \\
\hline & \multirow[t]{2}{*}{$\begin{array}{l}\text { Strategy \& } \\
\text { Structure }\end{array}$} & $\begin{array}{l}\text { Ranking of } \\
\text { world's best } \\
\text { performing } \\
\text { ceo (cl) } 2017 \text { - } \\
2019\end{array}$ & $\begin{array}{c}3 \text { year } \\
\text { average } \\
2017-19 \text {, } \\
\text { number in } \\
\text { list }\end{array}$ & $\begin{array}{c}\text { Harvard } \\
\text { Business } \\
\text { Review }\end{array}$ & Kim, 2018 \\
\hline & & $\begin{array}{l}\text { Image Abroad } \\
\text { (cl) 2017-2019 }\end{array}$ & $\begin{array}{c}3 \text { year } \\
\text { average } \\
2017-19, \\
\text { index } / 10\end{array}$ & $\begin{array}{c}\text { IMD World } \\
\text { Competitivenes } \\
\text { s }\end{array}$ & $\begin{array}{l}\text { Castro- } \\
\text { Gonzales, } \\
2016\end{array}$ \\
\hline
\end{tabular}

